\title{
Heat shock proteins and their role in early mammalian development
}

\author{
David A. Walsh, ${ }^{1,2}$ Marshall J. Edwards ${ }^{1}$ \\ and Murray S. R. Smith ${ }^{1}$ \\ 1 School of Anatomy, The University of New South Wales, \\ Sydney 2052, NSW, Australia \\ 2 Corresponding author \\ Accepted 12 June 1997 \\ Abbreviations: CNS, central nervous system; NTD, neural tube defects; HSP, heat \\ shock proteins; HSC, heat shock cognate proteins; MAP, mitogen activated proteins; \\ SAP, stress activated proteins; PG, prostaglandin; JNK, Jun kinase
}

\begin{abstract}
Elevated body temperature can result from many agents in the natural environment, such as fever, hot weather and heavy exercise. In our modern living conditions additional sources of induced hyperthermia including hot baths, saunas, drugs, electromagnetic radiation and ultrasound have been introduced. Hyperthermia during pregnancy has been shown to cause a wide spectrun of effects in all species studied, including humans, the outcome depending on the dose of heat absorbed by the mother and embryo and the stage of enbryonic or fetal development when exposed. The dose of heat is the product of the elevation of temperature above normal and the duration of the elevation. In relatively uncontrolled natural environmental exposures, embryonic death and resorption or abortion are probably the most common outcome. In less severe exposures (smaller doses) major or minor developmental defects can result and the central nervous system appears to be a major target for its effects. Heat damage to embryos appears to be by apoptotic and other forms of cell death in organs at critical stages of development. Over many millennia all living orgaisms appear to have developed protective mechanisms against excess heat, known collectively as the heat shock response. This response has been studied intensively over the last 20 years and its mechanisms of protection are now becoming more clearly defined. Exposures to heat (and a number of other toxic agents) trigger the heat shock response which is characterized by abrupt suspension in the
\end{abstract}

normal protein synthesis and the concurrent induction of heat shock genes (hsp) and the synthesis of a set of protein families known collectively as the heat shock proteins (HSP). The hsp are known to be involved in the response in embryos, each has at least two copies, one which appears to have functions in the normal embryonic development (cognate) and another which is induced at a certain dose of heat (induced) and which can offer some protection against damage for some time after the initiating dose. Most cognate HSP can normally be found in embryos at all stages of development. At certain critical, early stages of organ formation increased activity of one or more of the hsp families can be identified at the site of the organ analogue. The inducible HSP are usually undetectable during normal development and generally become inducible at these critical inductive stages of organ development, implying a protective function for that process. Excess heat is known to cause denaturation of proteins. Each of the known HSP families appears to protect cells through their chaperone functions in which they bind to adhesive sites on newly synthesized or heat damaged and partially unfolded structural and functional proteins. This prevents the formation of function-less aggregates. The damaged proteins are then either presented for degradation or are reconstituted by orderly disengagement from the chaperone protein. The molecular mechanisms of initiating and regulating the response are now becoming more clearly defined. Trigger mechanisms include release of prostaglandin A1 which can be modulated by glucocorticoids and nonsteroidal anti-inflammatory agents. A heat shock factor (HSF) binds to the heat shock element (hse) on the gene sequence and initiates the hsp response. The signal induction pathway involves mitogen activated proteins (MAP) and stress activated proteins (SAP) which are regulated by phosphorylation. Signals are amplified by kinase cascades while they are being transmitted to the nucleus. Activated MAP and SAP kinases regulate the process by phosphorylation of proteins including transcription factors, HSP, other protein kinases and phosphorylases, growth factor receptors and cytoskeletal proteins. Although this research has defined some pathways indicating how and why heat can cause some defects, a means of preventing them has not yet emerged.

Keywords: heat shock proteins, hyperthermia, cell cycle, apoptosis, central nervous system development 


\section{Hyperthermia as a cause of birth defects}

\section{Hyperthermia}

Hyperthermia is a condition of elevation of body temperature over the normal levels and heat shock is the response of cells to hyperthermia. Under normal conditions hyperthermia can have many causes including febrile infections, heavy exercise, a hot and humid environment, exposures to sauna baths, hot tubs, ultrasound and various electromagnetic and other irradiations, as well as by a number of drugs and organic compounds (Lomax, 1987). Combinations of these agents and conditions, especially if involving a hot, humid environment, can accentuate the liability to, and the degree of hyperthermia.

\section{History}

Although the teratogenic effects of hyperthermia on birds have been known since the last century (Dareste, 1877; Alsop, 1919), its possible effects in mammals were not examined systematically before 1960 . Before this time,
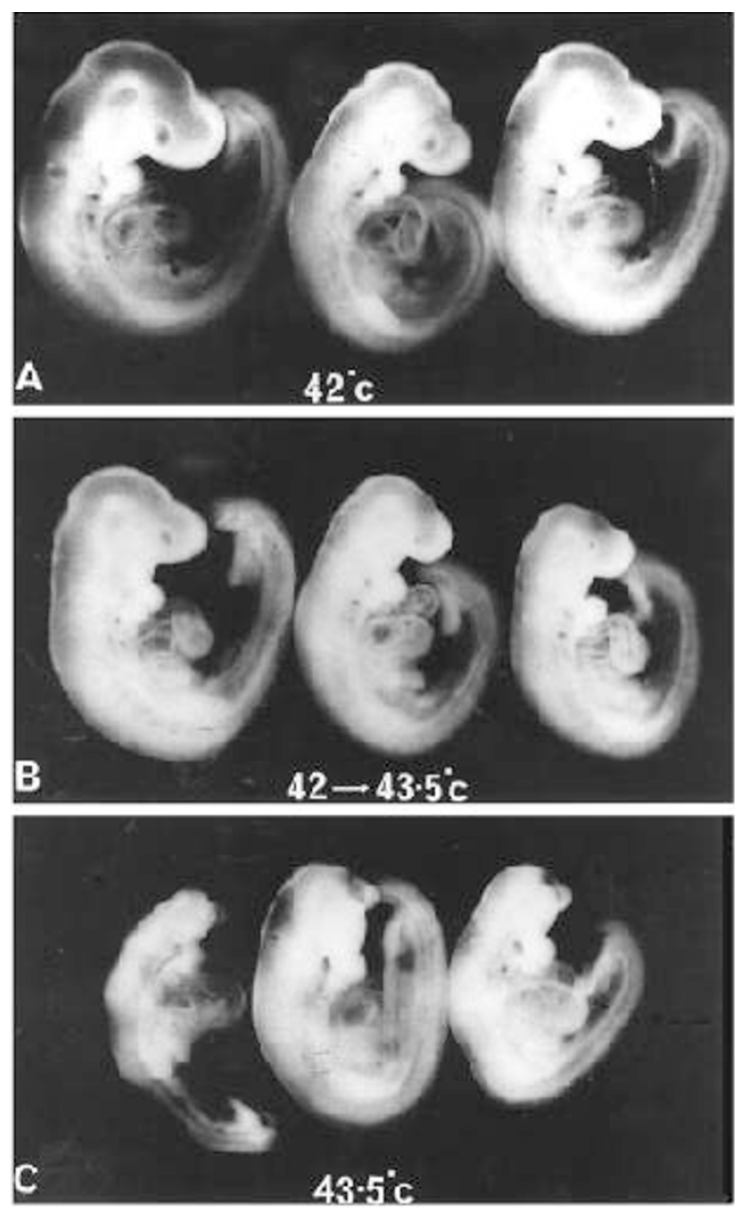

many studies had shown that maternal hyperthermia in many different species of farm and laboratory animals was a potent cause of prenatal death of embryos (Bell, 1987).

It is now accepted that maternal hyperthermia causes disturbances of prenatal development in animals, including humans (Edwards, 1986; Edwards et al., 1995). Significant experimental demonstration of its teratogenic effects has been published for mice (Webster and Edwards, 1984; Finnell et al., 1986; Shiota, 1988), rats in vivo (Skreb and Frank,1963; Edwards, 1967; Lary, 1982; Germain et al., 1985; Webster et al., 1985) and in vitro (Cockroft and New, 1975; Mirkes, 1985; Walsh et al., 1985; Kimmel et al., 1993) guinea pigs (Edwards, 1969; Hutchinson and Bowler, 1984; Upfold et al., 1989) hamsters (Kilham and Ferm, 1976) sheep (Hartley et al., 1974), pigs (Done et al., 1982) and monkeys (Poswillo et al., 1974; Hendrickx et al.,1979).

\section{Methods of induction and conditions causing hyperthermia}

Numerous methods have been used experimentally to cause elevations of embryonic and fetal temperatures. Most methods have involved elevation of the body temperatures of the mother, or of the maternal abdomen, at various stages of pregnancy and include the following: exposures in hot air chambers or incubators (Edwards 1967, 1968a; Hartley et al., 1974; Hendrickx et al., 1979; Done et al., 1982), immersion of the lower abdomen in warm water (Chernoff et al.,1985; Webster et al., 1985; Shiota 1988), immersion of the exteriorised pregnant uterus of anaes-thetised rats in warm water (Skreb and Frank, 1963), electromagnetic exposure (Lary et al., 1982; Brown-Woodman et al., 1988) and microwave irradiation of the abdomen and pregnant uterus (Fukui et al., 1992), maternal fever induced by the injection of boiled milk (Brinsmade and Rubsaamen, 1957) or endotoxins (Hellmann, 1977; Hilbelink, 1986) and administration of LSD to the mother (Freedman et al., 1981).

While many different methods have been used to elevate embryonic temperatures, the malformations resulting from these different agents all conform with a generally consistent pattern of defects, therefore it can

Figure 1. Whole embryo cultures showing 11.5 day rat embryos after a $48 \mathrm{~h}$ in vitro culture following exposure to a heat shock at 9.5 days pre-somite neural plate stage. Embryos were exposed to (A) $42^{\circ} \mathrm{C}$ for 7 min resulted in a characteristic heat shock response and no obvious developmental defect; (B) $42^{\circ} \mathrm{C}$ for $10 \mathrm{~min}$ (induced heat shock response) then embryos were cultured at $38.5^{\circ} \mathrm{C}$ for $1 \mathrm{~h}$ followed by a $43.5^{\circ} \mathrm{C}$ for $7.5 \mathrm{~min}$ (acquired thermotolerance). Embryos at neural plate stage exposed to $42^{\circ} \mathrm{C}$ and $42 / 43.5^{\circ} \mathrm{C}$ showed a $2-4 \mathrm{~h}$ growth delay but apparent normal development after $48 \mathrm{~h}$ (C) $43.5^{\circ} \mathrm{C}$ for $7.5 \mathrm{~min}$ was teratogenic. Embryos exposed to $43.5^{\circ} \mathrm{C}$ showed increasing severity of damage, particularly to the head and heart (note complete absence of developed forebrain and eye). 
reasonably be assumed that the defective development was a result of temperature elevation and not due to some other effect of the agent used to cause the elevation. Also, as malformations have been produced by elevated temperatures in embryos in culture (Cockroft and New, 1975), and in incubating chickens (Alsop, 1919), it is apparent that the defects are due to the direct effects of heat on the embryo and not caused indirectly through metabolic or toxic changes induced in the mother.

\section{Developmental defects caused by hyperthermia}

Hyperthermia can cause a wide range of defects, the type depending mainly on the stage of embryonic development when the exposure occurs. The incidence and severity of defects depends largely on the severity of exposure (dose of heat). A consistent feature of experimental studies with many different species of animals has been that the central nervous system (CNS) is the most susceptible to damage. Defects of the CNS can be severe and bizarre, such as anencephaly, exencephaly, encephalocele, microphthalmia or subtle such as various degrees of micrencephaly (Edwards, 1969b) associated with learning deficits (Lyle et al., 1977). The most sensitive period for neural tube defects (NTD) and microphthalmia is at the the neural plate stage of development, just prior to and during the early stages of tube closure, E8 in mice (Shiota, 1988), E9.5 in rats (Webster et al., 1985; Walsh et al , 1987 ) and E13-14 in guinea pigs (Harding and Edwards, 1993) (Figure 1). The most sensitive stage for micrencephaly is just prior to and during formation of the cortical plate (E13-14 in rats and E21 in guinea pigs) and precedes the intense phase of neuroepithelial proliferation which produces the neurons of the cerebral cortex. Another stage of sensitivity for micrencephaly in guinea pigs is during glial cell proliferation (days E39-46). The deficits in brain growth caused during neurogenesis and glial cell proliferation are permanent and produce severe learning problems (Edwards et al., 1976; Lyle et al., 1977). Hyperthermia during the phase of intense myelin production (days E53-60) is less severe, is made up during postnatal growth and does not result in learning deficits. Other CNS defects in guinea pigs include neurogenic clubfoot (after exposure about days E20-23), arthrogryposis (after exposures between days E30-42) and cranial nerve defects. Most of the defects of the CNS in experimental animals are at times accompanied by other abnormalities such as coloboma, facial clefting, maxillary hypoplasia, hypoplasias of teeth and toes, vertebral and tail abnormalities, exomphalos and renal agenesis (Edwards et al., 1995).

Most instances of defects in humans mirror the patterns in experimental animals in the range of abnormalities and relative timing of the exposure to hyperthermia. It is notable that abortion is a common sequel to a febrile episode (Kline et al., 1985) and it is probable that this is the outcome in most instances of maternal heat exposure (Graham and Edwards, 1988). Hyperthermia is associated with an increase in the plasma levels of prostaglandins (PGs) in the ewe and fetal lamb (Andrianakis et al., 1989) and is accompanied by increased uterine activity and fetal distress (Morishima et al., 1975). There are many reports of retrospective and prospective studies on the occurrence of NTD after maternal exposures to a range of conditions leading to elevations of temperature (Chance and Smith, 1978; Layde et al., 1980; Shiota, 1982; Hunter, 1984; Milunsky et al., 1992) and it has been estimated that maternal hyperthermia at the time of neural tube closure is the cause of about $10 \%$ of cases of NTD (Graham and Edwards, 1988). Other defects include microphthalmia (Spraggett and Fraser, 1982), neuronal heterotopias, microcephaly, micrognathia, mid-face hypoplasia, clefts of the lip and palate, hypotonias, neurogenic contractures, siezures. mental deficiency (Graham and Edwards, 1988) Moebius syndrome (Graham et al., 1988) and Hirschsprung disease (Lipson, 1988).

\section{Threshold levels of temperature elevation causing malformations}

Experimental data from a number of species has shown that in simple, uncomplicated cases of hyperthermia, defects can be caused by elevations over the normal body temperature of $2^{\circ} \mathrm{C}$ and above. However, the teratogenic threshold dose of heat has been shown to be a product of the temperature elevation and the duration of elevation. Recorded instances of defects being caused at elevations lower than $2^{\circ} \mathrm{C}$ even for extended periods of time are uncommon, although embryonic resorption and abortions might be associated with these lower elevations. In E21 guinea pig embryos, with a normal maternal body temperature of $39.5^{\circ} \mathrm{C}$, a slow elevation of $2^{\circ} \mathrm{C}$ to $41.5^{\circ} \mathrm{C}$ over a period of 60 min causes an increase in the incidence of micrencephaly. Similarly, in E9.5 rat embryos, an elevation of $2.5^{\circ} \mathrm{C}$ for $60 \mathrm{~min}$ (over the normal temperature of $38.5^{\circ} \mathrm{C}$ to $41^{\circ} \mathrm{C}$ ) or a brief "spike" pattern of elevation of $4.5^{\circ} \mathrm{C}$ results in a range of defects of the head (Germain et al., 1985). With E9.5 rat embryos in culture at $40^{\circ} \mathrm{C}$ or $41^{\circ} \mathrm{C}$ for $48 \mathrm{~h}$ (an elevation of $2^{\circ} \mathrm{C}$ and $3^{\circ} \mathrm{C}$ over the control incubation temperature of $38^{\circ} \mathrm{C}$ ), a similar pattern of neural tube and facial defects was found (Cockroft and New, 1975). Also in E10 rat embryos, a slow elevation over a period of about $30-40 \mathrm{~min}$ to $39.2-40.4^{\circ} \mathrm{C}$ (an elevation over temperatures of control animals of approximately 2$2.5^{\circ} \mathrm{C}$ ), caused a spectrum of skeletal malformations (Kimmell et al., 1993). A systematic study of the interactions between temperature elevation and duration of elevation, showed that as the temperature elevation becomes higher, the time required to cause malformation is reduced logarithmically (Germain et al., 1985).

One conclusion which might be drawn from these studies is that it appears more appropriate to relate 
critical threshholds to an elevation above normal level for a species or genotype, rather than to a single, actual temperature which applies to all species.

Although it is relatively simple to record the duration of temperature elevations in experimental animals, it is not a simple matter in the human clinical situation in which most elevations would be in the lower ranges. In fact, recording of temperatures in humans appears to be unusual (Edwards et al., 1995). All experimental evidence to date, indicates that maternal elevations less than $2^{\circ} \mathrm{C}$ even for extended periods appear not to be associated with embryonic damage leading to birth defects, and for this reason, to quote a simple threshold maternal temperature elevation of $2^{\circ} \mathrm{C}$, without a duration appears to be justified.

\section{Cell death and changes in the cell cycle after exposure to hyperthermia as a cause of malformation}

Apoptosis is an active form of cell death characterised by

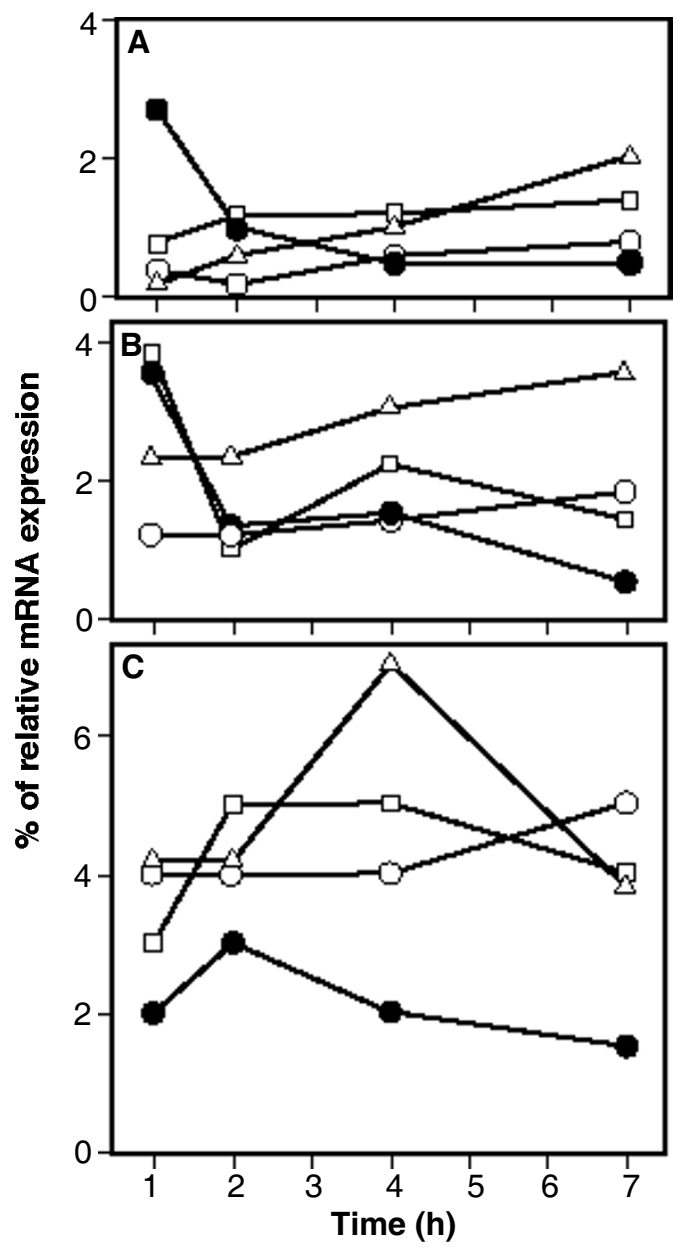

condensation of chromatin, which marginates against the nuclear membrane and later fragments, and shrinkage and condensation of the cellular contents within the intact cell membranes (Alison and Sarraf, 1992). In this form of cell death, the cellular contents remain isolated from surrounding tissues within the membranes which avoids inflammatory reactions. Apoptosis is a normal, gene-controlled event in embryogenesis (programmed cell death) which allows orderly disposal of cells during organogenesis when organ and body parts are being moulded into templates of their mature shapes (Glucksmann, 1951). It is also the normal means of disposal of supernumerary cells, for example, cells in the developing brain which fail to make appropriate connections to their intended targets. Another form of apoptosis, which has not been programmed genetically in embryos, is caused by a number of toxic agents, including hyperthermia.

In histological studies of embryos cultured at $40.5^{\circ} \mathrm{C}$ and $41^{\circ} \mathrm{C}$, Cockroft and New (1978) showed severe cell death particularly in the CNS. Neuroepithelial cell death was also the most notable feature in the developing CNS of heated E21 guinea pig embryos (Edwards et al., 1974; Wanner et al., 1976; Upfold et al., 1989), as well as in E8 mouse (Shiota, 1988) and E14 rat embryos in vivo (Skreb and Frank, 1963; Harding and Edwards, 1993). and E9.5-10.5 rat embryos in culture (Mirkes, 1985; Walsh et al., 1987; 1991; 1993). Cell death is the most prominent feature underlying the neural defects caused by heat and appears most severe in ectodermal structures. It is usually less severe in mesodermal cells and is infrequently found in endoderm. Mitotic cells of the neuroepithelium of E21 guinea pigs embryos are the most sensitive to heat, clumped chromosomes being found immediately after a spike elevation of approximately $2^{\circ} \mathrm{C}$. These cells die quickly and are phagocytosed by adjacent cells. After 4-8 $\mathrm{h}$, with an elevation of at least $3-3.5^{\circ} \mathrm{C}$, S-phase cells and some mesodermal cells die and this form of cell death has been identified as apoptosis. During the period between exposure and the appearance of apoptosis, normal mitotic activity in the neuroepithelium ceases. The onset of apoptosis is accompanied by a synchronized burst of mitotic activity (Edwards et al., 1974; Wanner et al., 1976; Upfold et al., 1989). The damaged M and S phase cells are removed by phagocytosis by macrophages and

Figure 2. The rapid cell cycle changes in early neurectoderm cells showing the percentage of relative mRNA expression and tight $h s p$ gene regulation in $h s p 90,71$ and 27 and $h s c 73 \mathrm{mRNA}$ over $7 \mathrm{~h}$ in the neurectoderm cells taken from neural plates at 9.5 day cultured rat embryos during $G_{0} / G_{1}$, early $S$ phase, late $S$ phase and $G_{2}+M$. (A) Control transcription rates; (B) $42^{\circ} \mathrm{C}$ for $10 \mathrm{~min}$ and; (C) $43.5^{\circ} \mathrm{C}$ for 7 min. Neurectoderm from day 9.5 embryos were sorted into cell cycle phases by flow cytometry and cells analysed by dot blot and Northern analysis at 1, 2, 4 and $7 \mathrm{~h}$ the time required for cell division shock. $\bigcirc, h s p 27 ; \square, h s c 73 ; \triangle$, hsp71;,$h s p 90$. 
adjacent normal neuroepithelial cells over the next $24 \mathrm{~h}$. In E9.5 cultured rat embryos (Walsh et al., 1991; 1993) a temperature of $42^{\circ} \mathrm{C}\left[+3.5^{\circ} \mathrm{C}\right]$ for 10 min causes minor rates of cell death in the $\mathrm{G} 2$ or mitotic phases of the cell cycle at approximately $5 \mathrm{~h}$ and also 12-15 $\mathrm{h}$ after exposure. No developmental abnormalities result from this dose of heat. However, a more severe exposure, known to be teratogenic $\left(43^{\circ} \mathrm{C}\left[+4.5^{\circ} \mathrm{C}\right]\right.$ for $\left.7.5 \mathrm{~min}\right)$, causes extensive apoptosis in the neurectoderm, particularly in the ridges of the neural folds at 3-5 $\mathrm{h}$ following exposure.

The death of S-phase cells in heated embryos is distinct from programmed apoptosis which is a normal embryological process (Glucksmann, 1951). In normal development, at the time of neurulation and the onset of rapid proliferation of neurones, apoptotic cells are rarely found. It was suggested that once dividing cells are committed to enter a cycle, apoptosis is initiated and can be prevented only when acceptable progression is made through the various phases of the cell cycle (Kung et al., 1990). It is apparent that thermal damage causes severe disruption of the cycle, possibly by denaturation of proteins and this might initiate the process of apoptosis. Following teratogenic doses of heat, large numbers of apoptotic cells are found in areas which are primordia of the malformed organs. Sufficient heat damage to the functional proteins of dividing embryonic cells might well prevent the successful completion of the immediate or the subsequent cycle and allow the apoptotic program to be implemented.

Flow cytometry studies (Walsh and Morris, 1989) found that heat caused a partial synchronisation of the generation cycle in neurectodermal cells by causing delays to progression for 1-2 $\mathrm{h}$ at the G1-S boundaries (Figure 2). There was also a barrier to cell progression at the SG2 boundary in cells given non-teratogenic exposures $\left(42^{\circ} \mathrm{C}\right.$ for $10 \mathrm{~min}$ or $42^{\circ} \mathrm{C}$ followed by $43^{\circ} \mathrm{C}$ for $7.5 \mathrm{~min}$ ). Squash preparations from the brains of E21 guinea pig embryos also showed blocks to progression through mitosis before prophase and during metaphase (Edwards et al., 1974).

\section{The heat shock (stress) response}

Ritossa (1962) described a "puffing" pattern in the polytene chromosomes of Drosophila pupae which had been exposed to abnormally high incubation temperatures. Subsequent research showed that the gene activity associated with this reaction initiated the "heat shock response" which offered some protection against thermal damage to tissues. It is now known that the response can be induced in a very wide range of animals, whether unicellular or multicellular, embryonic or mature and vertebrate or invertebrate by exposure to elevated temperatures. The response has also been identified and studied in plants. It is characterised by the abrupt suspension of normal protein synthesis soon after exposure to a sufficient dose of heat and this is followed by a rapid induction of synthesis by the heat shock genes ( $h s p)$ of a number of families of proteins termed the heat shock proteins (HSP) (Lindquist, 1986; Hightower, 1991). As the response was subsequently found to be elicited by some chemical and toxic agents it is also, perhaps more correctly termed the "stress response". Its conservation throughout the millennia of evolution from primitive to more complex organisms indicates the fundamental importance of the response to recovery from injury and survival.

\section{Heat shock families known to be associated with prenatal development}

The $h s p$ known to be of relevance in prenatal development include families which synthesize proteins with molecular weights in the region of $90 \mathrm{kDa}$ (HSP90), HSP70, HSP47. HSP2O and ubiquitin. Most HSP have at least two genes, one of which is induced by a stress to synthesize the HSP and another gene which in unstressed cells synthesizes heat shock cognate proteins (HSC) which are involved in normal cellular functions (Table 1).

Table 1. Heat shock proteins in mammalian embryos

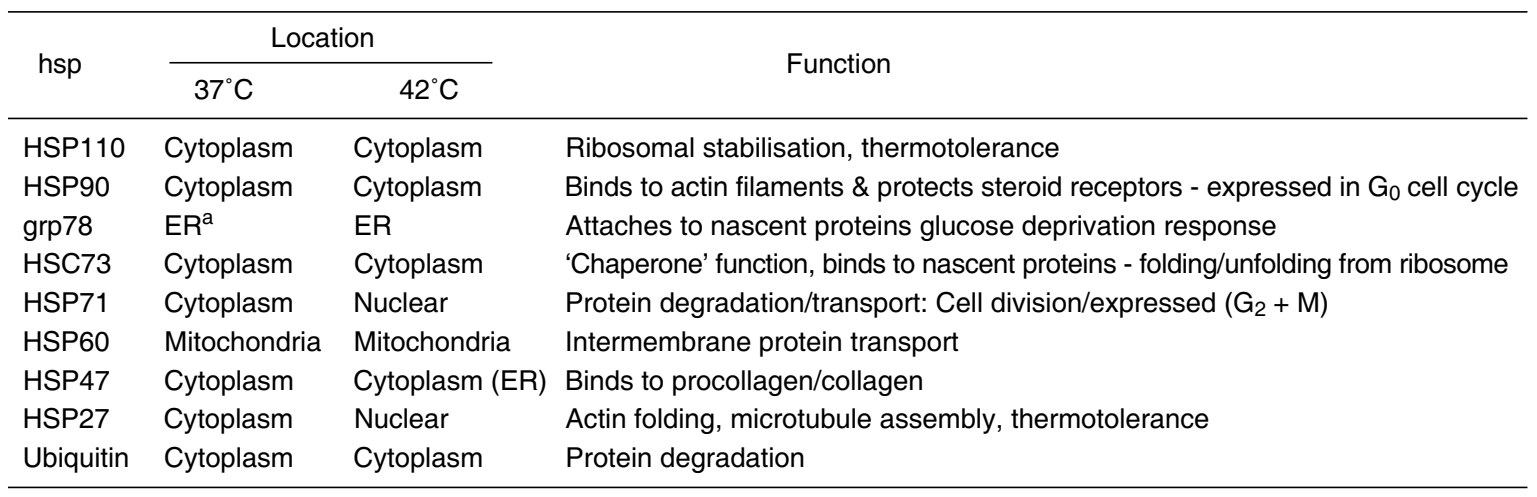

${ }^{a}$ Endoplasmic reticulum 
(i) HSP90 is moderately induced by heat having interactions with steroid receptors, actin and tubulin in the microtubules of interphase and mitotic spindles of dividing cells. HSC90 is present constitutively in relatively large quantities in the cytosol of normal unstressed cells.

(ii) In the hsp70 family, the induced HSP71 is found in very small amounts in normal cells but is strongly induced by hyperthermia when it is detected in the cytosol and nucleus. Its cognate, HSC73, is found normally in the cytosol and nucleus and is also moderately induced by hyperthermia.

(iii) Recently HSP47 has been identified as a stress protein (Nagata and Yamada, 1986; Nagata et al., 1986, 1988; Natsume et al., 1994; Satoh et al., 1996). It is a member of the serpin group, which binds to collagen types I-IV and is found in the endoplasmic reticulum. It is present constitutively and is also strongly induced by heat.

(iv) In mammals, the main member of the HSP2O family is HSP27. It also is present as an HSC associated with the actin cytoskeleton and is induced strongly by heat.

(v) Ubiquitin is the smallest of the HSP (MW. $10 \mathrm{kDa}$ ) and is present constitutively as a cognate associated with nuclear histone. It is also induced by heat, binding to damaged proteins.

Many families of stress proteins are present constitutively (cognate proteins or HSC) in normal unstressed cells and have a number of functions including "chaperone" functions through binding to newly synthesised proteins, facilitating their translocation, transport and folding into their functional configurations. These proteins were named chaperones because they protect newly synthesized proteins against inappropriate binding to uncovered active surfaces on other proteins to form functionless aggregates. Newly heat-induced HSP and some HSC bind to uncovered, adhesive sites on thermally sensitive proteins in the cytoplasm. Others translocate to the nucleus binding to, and protecting chromatin protein complexes (Lindquist, 1986; Schlesinger, 1990; Hightower, 1991). The families with chaperone functions include HSP90, HSP70, HSP47 and the small HSP. The heat inducible HSP and HSC appear to assist in reconstitution of heat damaged proteins after binding to them by an orderly disengagement to allow the resumption of the correct functional structure of the rescued protein.

\section{The HSP and HSC in prenatal development}

\section{Functions in normal development}

As a number of the HSP families are found in normally developing embryos, it can reasonably be assumed that they perform chaperone roles in normal embryogenesis. The HSC90 family has been detected in the E9.5 rat neurectoderm and is highly expressed at the $G_{0}$ phase (stationary, resting phase) of the cell cycle, with a possible function of maintaining cells at this phase until a signal initiates their entry into the active phase of the generation cycle (Walsh et al., 1993).

$\mathrm{HSC70}$ is expressed constitutively in preimplantation mouse embryos (Mezger et al., 1991), where it has been identified as early as the 2 cell stage. It is also found at high levels at the 8 cell stage and during subsequent development where this level is maintained. It is also normally present in rat embryos, being at high levels in the cytosol and nucleus during differentiation of the neural plate, neural tube closure and organogenesis (Walsh et al., 1989).

The functions of HSC47 have been studied recently using E7.5-11.5 rat embryos in culture (Walsh et al., 1997). In E7.5 embryos it was found only in the endoderm cells. At E8.5, it was present in ectoderm, mesoderm and endoderm of the embryo plus the allantois and yolk sac. During neural tube formation at E9.5 it was present in cells of the neurectoderm and mesoderm and its synthesis and location was coordinated closely with the production and location of collagen IV, including the basement membrane and extracellular matrix. However, collagen IV was not identified in the neuroepithelium of E9.5 embryos and did not appear until after the commencement of neural tube closure. At later stages, it was confined to more regionally specific areas of the brain, heart, pharyngeal arches and somites and again its location coincided with the patterns of distribution of collagens 1 and IV.

\section{Experimental in vitro studies}

Walsh et al., $(1985 ; 1987 ; 1989 ; 1993)$ studied the the expression of HSC and HSP using E9.5 rat embryos in culture (Figure 1). The embryo culture was carried out using a modified method of New et al. (1973) and involved culture from day E8.5 to $\mathrm{E} 11.5$ in a cabinet at $38.5^{\circ} \mathrm{C}$, the normal temperature of rats (Germain et al., 1985).

Groups of embryos designated for the experiments were allowed to develop to day E11.5 or to equilibrate at $38.5^{\circ} \mathrm{C}$ for $2.5 \mathrm{~h}$ and then be subjected to various regimes of temperature elevation after which they were returned to the incubating cabinet at $38.5^{\circ} \mathrm{C}$. A number of preliminary experiments defined the control levels of expression of HSP and the induced response, its duration, teratogenic exposures and subteratogenic exposures which appeared to confer protection against later teratogenic exposures. From these experiments a number of regimes of heat exposure were adopted to study the heat shock response.

After culture for $2.5 \mathrm{~h}$ at $38.5^{\circ} \mathrm{C}$, E9.5 embryos were allotted randomly to one of four groups:

(i). Controls, which were maintained at $38.5^{\circ} \mathrm{C}$ until day E11.5.

(ii). A group heated to $42^{\circ} \mathrm{C}$ for $10 \mathrm{~min}$ and then returned to $38.5^{\circ} \mathrm{C}$ until day E11.5. This treatment does not cause defects but after recovery for at least $15 \mathrm{~min}$ at $38.5^{\circ} \mathrm{C}$ these embryos have protection for about $8 \mathrm{~h}$ against a subsequent exposure to $43^{\circ} \mathrm{C}$ for $7.5 \mathrm{~min}$. 
(iii). A group exposed to $43^{\circ} \mathrm{C}$ for $7.5 \mathrm{~min}$ then cultured returned to $38.5^{\circ} \mathrm{C}$ until day 11.5 . This treatment causes severe developmental defects.

(iv). A group exposed to $42^{\circ} \mathrm{C}$ for $10 \mathrm{~min}$, returned to $38.5^{\circ} \mathrm{C}$ for $1 \mathrm{~h}$ and exposed to $43^{\circ} \mathrm{C}$ for $7.5 \mathrm{~min}$ and then returned to $38.5^{\circ} \mathrm{C}$ until day E11.5. These embryos show no obvious developmental defects.

Synthesis of the heat inducible HSP in preimplantation embryos can only be induced during a brief period after the first cleavage to form a 2 cell embryo. It cannot be induced between the 2 cell and blastocyst stages in mice and rabbits (Morange et al., 1984; Heikkila et al., 1985). After the blastocyst stage hyperthermia and some other stresses at the vulnerable stages, the heat shock transcription factor accumulates in the nucleus where it binds to the heat shock element in the chromosomes and transcription is initiated. As there is a high level of HSC and the HSP can be induced during these critical stages of organogenesis, a function of these stress proteins appears to be to provide some protection against damage caused by hyperthermia and the other stresses which induce their synthesis.

Using E9.5 rat embryos in culture, (Walsh et al., 1989; 1991; 1993; 1994), HSP90, HSC73 and HSP23-27 were demonstrated in normally developing embryos but HSP71 was not detected. At $1.5 \mathrm{~h}$ after the $43^{\circ} \mathrm{C}$ exposure a reduction in total protein synthesis was observed and at 2-3 $\mathrm{h}$ there was a large increase in the synthesis of HSP71, 73 and 90 which returned to normal by 6-8 $\mathrm{h}$.

HSP47 expression in E7.5 rat embryos, studied by immunohistochemical techniques was found to be confined to parietal endoderm cells (Walsh et al., 1997). At 8.5 days it was found in ectoderm, mesoderm and endoderm but on day 9.5 it was widespread throughout the ectoderm, mesoderm and endoderm plus the allantois and yolk sac and later it was found in more specific areas including the brain, pharyngeal arches, heart and somites. Except for ectodermal tissues, its distribution coincided with the expression of collagens I and IV except in ectodermal tissues in which they were not identified before neural tube closure.

The heat shock response induces changes in the levels of hsp27, 71 and 90 mRNA. Northern analysis did not detect $71 \mathrm{kDa}$ mRNA in control embryos but it was present in small quantities at 5-10 min after the $42^{\circ} \mathrm{C}$ exposure and within $2 \mathrm{~min}$ after $43^{\circ} \mathrm{C}$, reaching a peak level at 90 min with a decline to normal levels in $5 \mathrm{~h}$. The levels in embryos exposed to $42 / 43^{\circ} \mathrm{C}$ were much less than the $43^{\circ} \mathrm{C}$ group. HSC73 was present in all samples. Small amounts were found in controls and in embryos following exposure to $42^{\circ} \mathrm{C}$. Larger amounts were found in embryos after exposure to $43^{\circ} \mathrm{C}$ and $42 / 43^{\circ} \mathrm{C}$. HSP27 was induced rapidly and after $42^{\circ} \mathrm{C}$ rose to a moderate level between $0.5-3 \mathrm{~h}$ and then declined to normal levels by $6 \mathrm{~h}$. Much higher expression followied exposure to $43^{\circ} \mathrm{C}$ and the $42 / 43^{\circ} \mathrm{C}$ exposure resulted in levels lower than both the $42^{\circ} \mathrm{C}$ and $43^{\circ} \mathrm{C}$ responses. The response by hsp90 mRNA following $42 / 43^{\circ} \mathrm{C}$ was higher than that for $43^{\circ} \mathrm{C}$ which was higher than those for $42^{\circ} \mathrm{C}$, which indicates that the hsp90 mRNA response is proportional for the total dose of heat.

Rapid activation of $h s p 71$ occurred after $42^{\circ} \mathrm{C}$ as indicated by dot blot analyses . A 2-3 fold increase of mRNA was found in the nucleus at 20 min which increased over the next $60 \mathrm{~min}$ and then fell to control levels by 3-4 $\mathrm{h}$. The levels in the cytosol showed a similar response but returned to normal levels earlier, within $2.5 \mathrm{~h}$. Following exposure to $43^{\circ} \mathrm{C}$ the nuclear mRNA showed a similar increase within 20 min which was maintained for $4 \mathrm{~h}$ and then fell to base levels. The cytosol fraction also showed a large, rapid increase to a peak at $1.5 \mathrm{~h}$, falling rapidly to normal levels by $5 \mathrm{~h}$. The $h s c 73$ mRNA showed a modest increase within $60 \mathrm{~min}$ and embryos exposed to $42 / 43^{\circ} \mathrm{C}$ demonstrated an intermediate response.

In situ hybridisation studies using $h s p$ cDNA probes showed constitutive expression of $h s p 71$ only in the allantois and ectoplacental cone of control E9.5 embryos. After an exposure to $43^{\circ} \mathrm{C}$, maximum $h s p 71$ expression at 90-120 min was in the neurectoderm of the neural plate, its underlying mesoderm and at low levels in the endoderm. Expression was most marked around the anterior neuropore. In 10.5 and 11.5 day embryos given $43^{\circ} \mathrm{C}$, the overall $h s p 71$ expression was reduced being greatest around the mid- and hindbrain areas.

\section{The heat shock response in $\mathbf{1 0 . 5}$ day rat embryos}

Mirkes $(1985 ; 1987)$ used four treatment groups of day 10 (6-10 somite) rat embryos. Controls were cultured throughout at $37^{\circ} \mathrm{C}$. A second group was at $37^{\circ} \mathrm{C}$ throughout except for $30 \mathrm{~min}$ at $42^{\circ} \mathrm{C}$, given $1 \mathrm{~h}$ after the commencement of the culture. A third group was exposed to $37^{\circ} \mathrm{C}$ throughout, with $43^{\circ} \mathrm{C}$ for $30 \mathrm{~min}$ given at $2.5 \mathrm{~h}$, while a fourth group received exposures of 42 and $43^{\circ} \mathrm{C}$ as above, separated by $1 \mathrm{~h}$ at $37^{\circ} \mathrm{C}$. At examination on day 11 , the $42^{\circ} \mathrm{C}$ group did not differ from controls, the $43^{\circ} \mathrm{C}$ embryos had a high mortality and level of defects, while the $42 / 43^{\circ} \mathrm{C}$ embryos had partial protection against mortality and malformation.

Within $1 \mathrm{~h}$, the $43^{\circ} \mathrm{C}$ treatment induced the synthesis of eight proteins of $28,31.5,33.5,34,39,69,78$ and 82 $\mathrm{kDa}$. Two proteins ( 33.5 and $34 \mathrm{kDa}$ ) were also detected in control embryos. Synthesis of all induced proteins ceased 3 to $9 \mathrm{~h}$ after exposure except $28 \mathrm{kDa}$ which ceased at 1-3 h. Usually, normal protein synthesis is curtailed during the heat shock response but in these experiments, the $43^{\circ} \mathrm{C}$ embryos did not show this response. After the $42^{\circ} \mathrm{C}$ exposure, synthesis of $31.5,39$ and 69$\mathrm{kDa}$ proteins was induced and the combined treatment induced all proteins except for the $28 \mathrm{kDa}$ at about half the level of the $43^{\circ} \mathrm{C}$ treatment. 
Fisher et al. (1995) also induced heat shock in day 10 rat embryos in vivo and in vitro to examine the role of the heat shock response in the genesis of defects of somite segmentation which has been shown to result in vertebral and rib anomalies of the mid thoracic region (Cuff et al., 1993). After exposures in vivo to $42-42.5^{\circ} \mathrm{C}$ for $5 \mathrm{~min}$ or in vitro to $42-42.5^{\circ} \mathrm{C}$ for $15 \mathrm{~min}$, they found enhanced synthesis of a 70-kDa protein for 1 to $4 \mathrm{~h}$ and of a $90-\mathrm{kDa}$ protein for 1 to $8 \mathrm{~h}$. The $70-\mathrm{kDa}$ protein was identified by Western blot as an inducible HSP72 which accumulated and remained in the neurectoderm for $2-27 \mathrm{~h}$ after exposure. It was not detected in the somite mesoderm. There was a lag period of $18 \mathrm{~h}$ between accumulation of HSP72 and the appearance of abnormal segmentation. The severity of damage to somites was related to the dose of heat. The absence of heat shock response in the somite mesoderm was believed to explain its sensitivity to heat.

Mirkes et al. (1991) compared the response in days 9 (pre-somite), 10 (6-10 somite), 11 (21-25 somite) and 12 (31-35 somite) rat embryos which after equilibration for $1 \mathrm{~h}$ at $37^{\circ} \mathrm{C}$ were given $43^{\circ} \mathrm{C}$ for $15-60 \mathrm{~min}$ and then returned to $37^{\circ} \mathrm{C}$ for $1 \mathrm{~h}$ before processing. Northern blot analysis of $h s p 70$ mRNA showed a response which varied with the stage of development and the dose of heat. Day 9 embryos showed the greatest response which decreased during days 10 to 12 , especially with the $60 \mathrm{~min}$ dose. Agents other than heat can elicit a stress response. Mirkes and Cornel (1992) compared the effects arsenic with heat shock on 10 day rat embryos in vitro. Although the response appeared similar, the defects caused by the two treatments were different, hyperthermia causing more severe damage to the developing prosencephalon, rhombencephalon and eyes.

Mirkes and Doggett (1992), used a monoclonal antibody to HSP72 with Western blot analysis to identify this HSP72 in 10 day rat embryos exposed to temperatures of $40^{\circ} \mathrm{C}$ and above for various time periods. The smallest doses associated with synthesis were $41^{\circ} \mathrm{C}$ for $15 \mathrm{~min}$, $42^{\circ} \mathrm{C}$ for $15 \mathrm{~min}$ and $43^{\circ} \mathrm{C}$ for $2.5 \mathrm{~min}$. The smallest doses which causing defects were, $41^{\circ} \mathrm{C}$ for between 45 and $60 \mathrm{~min}, 42^{\circ} \mathrm{C}$ for between 15 and $30 \mathrm{~min}$ and $43^{\circ} \mathrm{C}$ for between 0 and $2.5 \mathrm{~min}$. HSP72 was detected at $2.5 \mathrm{~h}$ after exposure and persisted for 24-48 $\mathrm{h}$, which raises the possibility of it being used as a biomarker for an embryotoxic exposure conferring tolerance.

\section{Heat shock and the cell cycle}

Walsh and Morris (1989) studied the expression of stress proteins at various stages of the cell cycle of the neural plate of cultured E9.5 rat embryos (Figure 2). Flow cytometry was used to determine the levels of $h s p 27,71$ (inducible), 73 (constitutive) and 90 mRNA. The heat inducible HSP70 was found in unstressed embryos at very low levels only during late $S$ phase and $G_{2}+M$ phases and as the cell passed into the $G_{0}$ phase, it fell to undetectable levels. There was steady expression of $h s c 73$ throughout the cell cycle while hsp90 was expressed strongly at $\mathrm{G}_{0}$ $\mathrm{G}_{1}$ and $h s p 71$ at $\mathrm{G}_{2}-\mathrm{M}$ phases. After exposure to $42^{\circ} \mathrm{C}$ for $10 \mathrm{~min}$, levels of $h s p 27$ and $71 \mathrm{mRNA}$ were elevated at all stages of the cycle, and all $h s p$ in $\mathrm{G}_{0}-\mathrm{G}_{1}$ and late $\mathrm{S}$, while $h s c 73$ and $h s p 90$ were elevated particularly at late $S$ and $\mathrm{G}_{2}-\mathrm{M}$. Exposure to the $43^{\circ} \mathrm{C}$ produced very strong expression of $h s p 27$ throughout the cycle, and both $h s c 73$ and $h s p 71$ were elevated especially during $S$ and $\mathrm{G}_{2}-\mathrm{M}$.

It is possible that the different levels of response at these stages reflect different levels of heat damage to the exposed cells. This proposal is reinforced by the lower levels of $h s p$ mRNA found after the combined treatments of $42^{\circ} \mathrm{C}$ followed by $43^{\circ} \mathrm{C}$, which does not result in defects. Even though the total dose of heat was larger in this group, the levels of all hsp mRNA were less than for either of the single treatments.

\section{Induction of HSP}

Extracellular events causing changes in the immediate cellular environment initiate responses which act through a signal induction pathway involving mitogen activated proteins (MAP) and stress activated proteins (SAP). As the signals are being transmitted to the nucleus, they are amplified by kinase cascades in multiple biochemical pathways through which specific programs of gene activity are induced. The activated MAP and SAP kinases regulate physiological processes by phosphorylation of proteins (Finnin et al., 1997). Normal embryonic development depends on rigid control of cellular proliferation and differentiation. MAP and SAP kinases are regulated tightly by phosphorylation (Clarke, 1994) and they regulate other proteins such as HSP, transcription factors, other protein kinases and protein phosphorylases, growth factor receptors and cytoskeletal proteins, by phosphorylation.

\section{Signal transduction pathways}

Although the immediate signals which activate the heat shock response are poorly defined, some recent observations might lead to a clearer understanding of the mechanisms. Andrianakis et al. (1989) exposed pregnant sheep to a hot environment which elevated the maternal and fetal temperatures and caused elevation of prostaglandin (PG) plasma levels in the mother and fetus. Inhibition of $P G$ synthesis caused fetal distress and at times, fetal death. Rossi et al., (1997), showed that prostaglandin A1 (PGA1) acted as an intracellular signal, inhibiting nuclear factor (NF) kappa B by inhibiting phosphorylation and preventing degradation of the NF kappa B inhibitor. PGA1 also caused the activation of the heat shock transcription factor which induced $h s p 70$ expression in cultured human cells (Ella et al., 1996). It is likely that a number of other factors also modulate the 
heat shock response, including endogenous glucocorticoids (Coelho et al., 1995).

In organisms as diverse as yeast and mammals, MAP and SAP kinases are the targets of a series of thre-tiered kinase cascades. The first group of kinases to be activated are the MAP/SAP kinase kinase kinases including the serine/threonine kinases, MEKK1 and Raf-1 (a product of the c-raf proto-oncogene). They then phosphorylate MAP/SAP kinase kinases (MEK, including MEK1, SEK1 and RKK) which in turn phosphorylate MAP and SAP kinases. MEK activates both MAP and SAP kinases by phosphorylating the threonine and tyrosine residues in specific motifs (Davis, 1994). The best understood example of activation of MAP/SAP kinase involves the phosphorylation of the p44 and p42 MAP kinases (extracellular-signal regulated kinases, ERK-1 and ERK-2). ERK-1 and ERK-2 were first identified as the kinases which phosphorylate ribosomal subunit kinase as a response to growth factor stimulation. They were then shown to respond to a range of stimuli which engage receptor tyrosine kinases, non-tyrosine kinase receptors and G-protein coupled receptors (Davis, 1994; Marshall, 1994; Waskiewicz and Cooper, 1995).

When a growth factor binds to its receptor, it induces receptor dimerization and phosphorylation, leading to recruitment of intracellular adaptor proteins and GDP/ GTP exchange factors such as Grb-2, SOS and Ras to the receptor complex. Ras activates Raf- 1 by recruiting it to the plasma membrane. Raf-1 phosphorylates the MAP kinase kinase MEK1, which in turn phosphorylates ERK1 and ERK-2 (Davis, 1994; Marshall, 1994). In addition to phosphorylating cytoplasmic proteins, activated ERK moves to the nucleus and regulates gene expression by phosphorylating transcription factors such as elk-1 (Davis, 1994; Marshall, 1994).

The SAP kinases are a distinct sub-group of the MAPlike kinases. Two Jun kinase (JNK) isoforms, p46 JNK1 and p54 JNK2 were originally identified as kinases that phosphorylate the activation domain of the transcription factor c-Jun (Davis, 1994). JNKs are activated by environmental stress, UV irradiation and stimulation with proinflammatory cytokines by phosphorylation of threonine and tyrosine in a T-P-Y motif. This activation cascade is similar to, but distinct from the cascade that activated ERKs. Dual phosphorylation of another SAPKs-p38 MAPK or reactivating kinase-p38 MAPK or reactivating kinase (RK) occurs in response to osmotic shock or when cells are stimulated under the conditions that lead to JNK activation.

Like ERK-1 and ERK-2, SAP kinases phosphorylate a number of proteins including nuclear transcription factors (Han, 1994). In contrast, nerve growth factor (NGF) withdrawal from cells can result in apoptosis leading to sustained activation of JNK and p38 kinases. Using JNK, p38 and ERK signalling pathways it was shown that activating JNK and p38 and concurrent inhibition of ERK are critical for inducing apoptosis. Therefore a dynamic balance between growth factor activated ERK and stress activated JNK and p39 pathways seems to be important in determining whether a cell survives or undergoes apoptosis (Zhengui et al., 1995; Verheij et al., 1996). Aberrant or constitutive activation of MAP and SAP kinases resulting from disrupted down-regulation of the active MAP/SAP kinases appears to lead to oncogenic changes.

There must be rigid control mechanisms to ensure accurate kinase regulation in terms of timing and intracellular location. Constitutive activation of MAP kinases by viral homologues of Ras and Raf-1 is an important underlying mechanism in tumorigenesis mediated by oncoproteins (Waskiewicz, 1995) which is consistent with deregulation of MAPK and SAPK activity contributing to oncogenesis.

\section{Concluding remarks}

The stress response has been highly conserved through evolution from primitive to complex organisms which indicates a critical function in many life processes. The roles and mechanisms of HSP in facilitating folding and unfolding, transport and reconstitution of proteins within the cells of embryonic and mature organisms needs further investigation. The cellular processes which induce and regulate the functions of HSP during normal and stressed conditions are still incompletely understood. With the use of recently developed transgenic animal models for gene knockout or overexpression and antisense strategies a more complete understanding of Heat Shock Proteins in prenatal development should be obtained.

\section{References}

Alison, M. R. and Sarraf, C. E. (1992) Apoptosis: a gene-directed pro-gramme of cell death. J. Roy. Coll. Phys. Lond. 26: 25-35

Alsop, F. M. (1919) The effect of abnormal temperatures upon the developing nervous system in the chick embryos. Anat. Rec. 15: 307-331

Andrianakis, P., Walker, D. D., Ralph, M. M. and Thorburn, G. D. (1989) Effect of inhibiting prostaglandin synthesis in pregnant sheep 4-amino antipyrine under normothermic and hyperthermic conditions. Am. J. Obstet. Gynecol. 161: 241-247

Angles, J. M., Walsh, D. A., Li, K., Barnett, S. B. and Edwards, M. J. (1990) Effects of pulsed ultrasound and temperature on the development of rat embryos in culture. Teratology 42: 285-293

Bell, A. W. (1987) Consequences of severe heat stress for fetal develop-ment. In Heat Stress: Physical Exertion and Environment. (Hales, J. R. S. and Richards D. A. B., eds.), Exerpta Medica, pp. 313-333, Elsevier Science, Amsterdam

Brinsmade, A. B. and Rubsaamen, H. (1957) Zur teratogenetischen Wirkung von unspezifischem Fieber auf den sich entwickelnden Kanin-chemembryo. Bietr. Path. Anat. 117: 154-164

Brown-Woodman, P. D. C., Hadley, J. A., Waterhouse, J. and Webster, W. S. (1988) Teratogenic effects of exposure to radiofrequency radiation $(2712 \mathrm{MHz})$ from a shortwave diathermy unit. Indust. Health 26: 1-10 
Chernoff, G. F., Golden, J. A. and Seymour, M. A. (1985) Neural tube closure in mouse embryos following a hyperthermic exposure. Proc. D. W. Smith Conf. June 12-14

Clarke, P. R. (1994) Signal transduction. Switching of MAP kinase. Curr. Biol. 4:647

Cockroft, D. L. and New, D. A. T. (1975) Effects of hyperthermia on rat embryos in culture. Nature 258: 604-606

Cockroft, D. L. and New, D. A. T. (1978) Abnormalities induced in cultured rat embryos by hyperthermia. Teratology 17: 277-284

Coelho, M. M., Luheshi, G., Hopkins, S. J., Pela, I. R. and Rothwell, N. J. (1995) Multiple mechanisms mediate antipyretic action of glucocorti-coids. Am. J. Physiol. 269: R527-535

Cuff, J. M., Kimmel, G. L., Kimmel, C. A., Heredia, D. J., Tudor, N. and Chen, J. (1993) The relationship between abnormal somite development and thoracic skeletal defects in rats following heat exposure. Teratology 48: 259-266

Dareste, C. (1877) Recherches sur la production artificielle des monstruo-sites, ou essais de teratogenie experimentale. Reinwald, Paris.

Davis, R. J. (1994) MAPKs: new JNK expands the group. Trends Biochem. Sci. 19: 470473

Done, J. T., Wrathall, A. E. and Richardson, C. (1982) Fetopathogenicity of maternal hypethermia at mid-gestation. Proc. Int. Pig Vet. Soc. (Mexico), pp. 252

Edwards, M. J. (1967) Congenital malformations in the rat following induced hyperthermia during gestation. Teratology 1: 173-177

Edwards, M. J. (1969a) Congenital defects in guinea pigs: Fetal resorp-tions, abortions and malformations following induced hyperthermia during early gestation. Teratology 2 : 313-328

Edwards, M. J. (1969b) Congenital defects in guinea pigs: Retardation of brain growth of guinea pigs following hyperthermia during gestation. Teratology 2: 329-336

Edwards, M. J. (1971) The experimental production of clubfoot in guinea pigs by maternal hyperthermia during gestation. J. Pathol. 103: 49-53

Edwards, M. J. (1981) Clinical disorders of fetal brain development: Defects due to hyperthermia. In Fetal Brain Disorders - Recent Approaches to the Problem of Mental Deficiency (Hetzel, B. S. and Smith, R. M., eds.), pp. 335-364, Elsevier/North Holland Biomedical Press, Amsterdam

Edwards, M. J. (1986) Hyperthermia as a teratogen: A review of experi-mental studies and their clinical significance. Teratogenesis Carcinog. Mutagen. 6: 563-582

Edwards, M. J., Mulley, R. C., Ring, S. and Wanner, R. A. (1974) Mitotic cell death and delay of mitotic activity in guinea-pig embryos following brief maternal hyperthermia. $\mathrm{J}$. Embryol. Exp. Morph. 32: 593-602

Edwards, M. J., Shiota, K., Smith, M. S. R. and Walsh, D. A. (1995) Hyperthermia and birth defects. Reprod. Toxicol. 9: 411-425

Edwards, M. J., Wanner, R. A. and Mulley, R. C. (1976) Growth and development of the brain in normal and heat-retarded guinea pigs. Neuropathol. Appl. Neurobiol. 2: 439-450

Ella, G., Amici, C., Rossi, A. and Santoro, M. G. (1996) Modulation of prostaglandin A1induced thermotolerance by quercetin in human leukemic cells: role of heat shock protein. Cancer Res. 56: 210-217

Finnell, R. H., Moon, S. P., Abbott, L. C., Golden, J. A. and Chernoff, G. F. (1986) Strain difference in heat-induced neural tube defects in mice. Teratology 33: 247-252

Finnin, P. J., Richardson, I. B., Grumont, R. J. and Gerondakis, S. (1997) Regulating MAP and SAP kinases. Life Sci. 9: 40-44

Fisher, B. R., Heredia, D. J. and Brown K. M. (1995) Induction of hsp72 in heat treated rat embryos: A tissue specific response. Teratology 52: 90-100

Freedman, M. S., Clark, B. D., Cruz, T. F., Gurd, J. W. and Brown, I. R. (1981) Selective effects of LSD and hyperthermia on the synthesis of synaptic proteins and glycoproteins. Brain Res. 207: 129-145
Fukui, Y., Hoshino, K., Inouye, M. and Kameyama, Y. (1992) Effects of hyperthermia induced by microwave irradiation on brain development in mice. J. Radiat. Res. 33: 1-10

Germain, M.-A., Webster, W. S. and Edwards, M. J. (1985) Hyperthermia as a teratogen: Parameters determining hyperthermia-induced head defects in the rat. Teratology 31: $265-272$

Glucksman, A. (1951) Cell deaths in normal vertebrate ontogeny. Biol. Rev. 26: 59-86

Graham, J. M. and Edwards, M. J. (1988) Teratogenic effects of maternal hyperthermia. Ann. Res. Inst. Environ. Med. (Nagoya) 40: 365-374

Graham, J. M., Edwards, M. J., Lipson, A. H., Webster, W. S. and Edwards, M. (1988) Gestational hyperthermia as a cause for Moebius syndrome. Teratology 37: 461-462

Han, J., Lee, J. D., Bibbs, L. and Ulevitch, R. J. (1994) A MAP kinase targeted by endotoxin and hyperosmolarity in mammalian cells. Science 265 : 808-811

Harding, A. J. and Edwards, M. J. (1993) Micrencephaly in rats caused by maternal hyperthermia on days 13 and 14 of pregnancy. Cong. Anom. 33: 203-209

Hartley, W. J., Alexander, G. and Edwards, M. J. (1974) Brain cavitation and micrencephaly in lambs exposed to prenatal hyperthermia. Teratology 9: 299-303

Heikkila, J. J., Miller, J. G. O., Schultz, G. A., Kloc, M., and Browder, L. W. (1985) Heat shock gene expression during early animal development. In Changes in Eukaryote Gene Expression in Response to Environmental Stress (Atkinson, B. G. and Walden, D. B., eds.), pp. 135-138, Academic Press, Orlando

Hellmann, W. (1977) Endotoxin fever and anomalies of development in rabbits. Arzneimittel Forsch. 29: 1062-1064

Hendrickx, A. G., Stone, G. W., Hendrickson, R. V. and Matayoshi, K. (1979) Teratogenic effects of hyperthermia in the bonnet monkey (Macaaca radiata). Teratology 19: 177-182

Hightower, L. E. (1991) Heat shock, stress proteins, chaperons and proteotoxicity. Cell 66: $1-20$

Hilbelink, D. R., Chen, L. T. and Bryant, M. (1986) Endotoxin-induced hyperthermia in pregnant golden hamsters. Teratogenesis Carcinog. Mutagen. 6: 209-217

Hutchinson, R. and Bowler, K (1984) The effect of hyperthermia on the development of the brain in the guinea pig. Dev. Brain Res. 14: 219-227

Hunter, A. G. W. (1984) Neural tube defects in Eastern Ontario and Western Quebec: Demography and family data. Am. J. Med. Genet. 19: 45-63

Johnson, H. A. and Pavelec, M. (1972) Thermal injury due to normal body temperature. Am. J. Pathol. 66: 557-564

Kilham, L. and Ferm, V. H. (1976) Exencephaly in fetal hamsters following exposure to hyperthermia. Teratology 14: 323-326

Kimmel, C. A., Cuff, J. M., Kimmel, G. L., Heredia, D. J., Tudor, N., Silverman, P. M. and Chen, J. (1993) Skeletal development following heat exposure in the rat. Teratology 47: $229-242$

Kline, J., Stein, Z., Susser, M. and Warburton, D. (1985) Fever during pregnancy and spontaneous abortion. Am. J. Epidemiol. 121: 832-842

Kung, A. L., Sherwood, S. W. and Schimke, R. T. (1990) Cell line specific differences in the control of cell cycle progression in the abscence of mitosis. Proc. Nat. Acad. Sci. USA 87: 9553-9557

Lary, J. M., Conover, D. L., Foley, E. D. and Hanser, P. L. (1982) Terato-genic effects of $2712 \mathrm{MHz}$ radiofrequency in rats. Teratology 26: 299-309

Layde, P. M., Edmonds, L. D. and Erickson, J. D. (1980) Maternal fever and neural tube defects. Teratology 21: 195-108

Lindquist, S. (1986) The heat shock response. Annu. Rev. Biochem. 55: 1151-1191

Lipson, A. (1988) Hirschsprung disease in the offspring of mothers exposed to hyperthermia during pregnancy. Am. J. Med. Genet. 29: 117-124

Lomax, P. (1987) Implications of drugs for heat and exercise tolerance. In Heat Stress: 
Physical Exertion and Environment (Hales, J.R.S. and Richards, D.A.B., eds.), pp. 399418, Exerpta Medica, Elsevier Sience, Amsterdam

Lyle, J. G., Edwards, M. J. and Jonson, K. (1977) Critical periods and the effects of prenatal heat stress on the learning and brain growth of mature guinea pigs. Biobehav. Rev. 1: 1-17

Marshall, C.J. (1994) MAP kinase kinase kinase, MAP kinase kinase and MAP kinase. Curr. Opin. Gene Devel. 4: 84-89

Mezger, V., Legagneux, V., Babinet, C. Morange, M. and Bensaude, O. (1991) Heat shock synthesis in preimplantation mouse embryos and embryonal carcinoma cells. In Heat Shock and Development (Hightower, L. and Nover, L., eds.), pp. 153-166, Springer-Verlag, Berlin

Milunsky, A., Ulcickas, M., Rothman, K. J., Willett, W., Jick, S. S. and Jick, H. (1992) Maternal heat exposure and neural tube defects. JAMA 268: 882-885

Mirkes. P. E. (1985) Effects of acute exposure to elevated temperatures on rat embryo growth and development in vitro. Teratology 32: 259-266

Mirkes, P. E. (1987) Hyperthermia-induced heat shock response and thermotolerance in postimplantation rat embryos. Devel. Biol. 119: 115-122

Mirkes, P. E. and Doggett, B. (1992) Accumulation of heat shock protein 72 (hsp72) in postimplantation rat embryos after exposure to various periods of hyperthermia (40$43^{\circ} \mathrm{C}$ ) in vitro: Evidence that heat shock protein 72 is a biomarker of heat-induced embryotoxicity. Teratology 46: 301-309

Morange, M., Diu, A., Bensaude, O. and Babinet, C. (1984) Altered expression of heat shock proteins in embryonal carcinoma cells and mouse early embryonic cells. Mol. Cell. Biol. 4:730-735

Morishima, H. O., Glaser, B., Biermann, W. H. and James, L. S. (1975) Increased uterine activity and fetal deterioration during maternal hyperthermia. Am. J. Obstet. Gynecol. 121: $531-538$

Nagata, K. and Yamada, K. M. (1986) Phosphorylation and transformation sensitivity of a major collagen-binding protein of fibroblasts. J. Biol. Chem 261: 7531-7536

Nagata, K., Saga, S. and Yamada, K. M. (1986) A major collagen-binding protein of chick embryo fibroblasts is a novel heat shock protein. J. Cell Biol. 103: 223-229

Nagata, K., Hirayoshi, K., Obara, M., Saga, S. and Yamada, K. (1988) Biosynthesis of a novel transformation-sensitive heat shock protein that binds to collagen. J. Biol. Chem. 263: $8344-8349$

Natsume, T., Koide, T., Yokota, S., Hirayoshi, K and Nagata, K. (1994) Interactions between collagen-binding stress protein HSP47 and collagen: Analysis of kinetic parameters by surface plasmon resonance biosensor. J. Biol. Chem. 269: 31224-31228

New, D. A. T., Coppola, P. T. and Terry, S. (1973) Culture of explanted rat embryos in rotating tubes. J. Reprod. Fertil. 35: 135-138

Poswillo, D., Nunnerley, H., Sopher, D. and Keith, J. (1974) Hyperthermia as a teratogenic agent. Ann. Roy. Coll. Surg. Engl. 55: 171-174

Ritossa, F. M. (1962) A new puffing pattern induced by heat shock and DNP in Drosophila. Experientia 18: 571-573

Rossi, A., Ella, G. and Santoro, M. G. (1997) Inhibition of nuclear factor kappa B by prostaglandin $\mathrm{A} 1$ : an effect associated with heat shock transcription factor activation. Proc. Nat. Acad. Sci. USA 94: 746-750

Satoh, M., Hirayoshi, K., Yokota, S., Hosokawa, N. and Nagata, K (1966) Intra-cellular interaction of collagen-specific stress protein HSP47 with newly synthesised procollagen. J. Cell Biochem. 133: 469-483

Schlesinger, M. J. (1990) Heat shock proteins. J. Biol. Chem. 265: 12111-12114

Shiota, K (1982) Neural tube defects and maternal hyperthermia in early pregnancy: Epidemiology in a human embryonic population. Am. J. Med. Genet. 12: 281-288

Shiota, K. (1988) Induction of neural tube defects and skeletal malfor-mations in mice following brief hyperthermia in utero. Biol. Neonate 53: 86-97
Shiota, K., Shionoya, Y., Ide, M., Uenobe, F., Kuwahara, C. and Fukui, Y. (1988) Teratogenic interaction of ethanol and hyperthermia in mice. Proc. Soc. Exp. Biol. Med. 187: $142-148$

Skreb, N. and Frank, Z. (1963) Developmental abnormalities in the rat induced by heat shock. J. Embryol. Exp. Morph. 11: 445-457

Spraggett, K. and Fraser, F. C. (1982) Sauna-induced hyperthermia in women. Teratology 25: 50-53

Upfold, J. B., Smith, M. S. R. and Edwards, M. J. (1989) Quantitative study of the effects of maternal hyperthermia on cell death and proliferation in the guinea pig brain on day 21 of pregnancy. Teratology 39: 173-179

Verheij, M., Bose, R., Lin, X. H., Yao, B., Yarris, W. D., Grant, S., Birrer, M. J., Szabo, E., Zon, L. I., Kyriakis, J. M., Haimovitz-Friedman, A., Fuks, Z. and Kolesnicks, N. S. (1995) Requirement for ceramide-initiated SAPK/JNK signalling in stress initiated apoptosis. Nature 380: 75-79

Walsh, D. A., Hightower, L. E., Klein, N. W. and Edwards, M. J. (1985) The induction of the heat shock proteins during early mammalian development. In Heat shock, Cold Spring Harbor Laboratory Symposium, Vol 2, p.92 (Abstr.), Cold Spring Harbor

Walsh, D. A., Klein, N. W., Hightower, L. E. and Edwards, M. J. (1987) Heat shock and thermotolerance during early rat embryo development. Teratology 36: 181-191

Walsh, D. A., Li, K., Speirs, J., Crowther, C. E. and Edwards, M. J. (1989) Regulation of the inducible heat shock 71 genes in early neural develop-ment of cultured rat embryos. Teratology 40: 312-334

Walsh, D. A., Li, K., Marsh, D., and Edwards, M. J. (1991) Thermotolerance and heat shock response during early development of the mammalian embryo. In Heat Shock and Development (Hightower, L. and Nover, V., eds.), pp. 58-69, Springer Verlag, Berlin

Walsh, D., Li, K., Wass, J., Dolnikov, A., Zeng, F., Li, Z. and Edwards, M. (1993) Heatshock gene expression and cell cycle changes during mammalian embryonic development. Devel. Genet. 14: 127-136

Walsh, D. A., Zhe, L., Zeng, F., Yan, W. and Edwards, M. J. (1994) Heat shock genes and cell cycle regulation during early mammalian develop-ment. Environ. Med. 38: 1-6

Walsh, D. A., Li, K., Wu, Y. and Nagata, K. (1997) Heat shock and the role of HSPs during neural plate induction and early mammalian CNS development. Cell. Mol. Life Sci. 53: 198-211

Wanner, R. A., Edwards, M. J. and Wright, R. G. (1975) The effect of hyperthermia on the neuroepithelium of the 21-day guinea-pig foetus: Histologic and ultrastructural study. J. Pathol. 118: 235-244

Waskiewicz, A. J. and Cooper J. A. (1995) Mitogen and stress response pathways. MAP kinase cascades and phosphatase regulation in mammals and yeast. Curr. Opin. Cell. Biol. 7: 798-805

Webster, W. S. and Edwards, M. J. (1984) Hyperthermia and the induction of neural tube defects in mice. Teratology 29: 417-425

Webster, W. S., Germain, M.-A. and Edwards, M. J. (1985) The induction of microphthalmia, encephalocele and other head defects following hyperthermia during the gastrulation process in the rat. Teratology 31: 73-82

Zhengui, X., Dickens, M., Raingeaud, J., Davis, R. J. and Greenberg, M. (1995) Opposing effects of ERK and JNK-p38 MAP kinase on apoptosis. Science 270: 1326 
150 Exp. Mol. Med. 